DOI: http://dx.doi.org/10.33846/hn30501

http://heanoti.com/index.php/hn

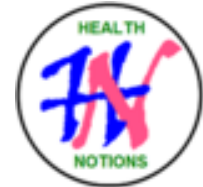

RESEARCH ARTICLE

URL of this article: http://heanoti.com/index.php/hn/article/view/hn30501

\title{
Behavior of Mother in Giving Foods to Children in The Kekei, Kiribun, Sokamu, and Kokamu Village of Dekai Subdistrict in Yahukimo District
}

\author{
Martapina Anggai ${ }^{1(\mathrm{CA})}$ \\ ${ }^{1(\mathrm{CA})}$ Study Program of Public Health, Faculty of Public Health, Cenderawasih University of Papua, Indonesia; \\ mariamartafkm@gmail.com (Corresponding Author)
}

\begin{abstract}
Nutrition is the most important part of a child's growth and development which is related to intelligence and health. Nutritional status of children is influenced by many factors, both directly and indirectly. This study aims to obtain an overview of the behavior of mothers and fulfill the nutritional status of children in Kekei, Kiribun, Kokamu and Sokamu villages in Dekai Subdistrict, Yahukimo District. This study involved mothers of Momuna tribe who had children aged 12 to 60 months in The Kekei, Kiribun, Kokamu, Sokamu village, Yahokimo district, as many as 112 respondents. The sampling technique used multistage random sampling and consecutive sampling. The results of this study showed that $92 \%$ of knowledgeable mothers were lacking and $8 \%$ were good. Mothers have less attitudes $94 \%$ and $6 \%$ good. Mothers behave less in fulfilling toddler nutrition $87 \%$ and good $13 \%$. The results of this study indicate conditions that are of concern and need continuous handling from both the government, the community and even the local tradition leaders for the recovery of the toddler's nutrition.
\end{abstract}

Keywords: Mother behavior, Feeding, Toddler children

\section{INTRODUCTION}

\section{Background}

Health is a normal and prosperous state of the body, social and mental to someone to be able to do katifitas without interference which means that there is a continuity of physical, mental, and social health of a person, including interaction with the environment ${ }^{(1)}$. Nutrition is one important factor that determines the level of health and harmony between physical development and mental development. The level of normal nutrition is achieved if optimal nutritional needs are met. A person's nutritional level in one period is not only determined by the consumption of nutrients in the past, even long before that time ${ }^{(2)}$. Increased knowledge about nutrition can be carried out by nutrition education programs carried out by the government. nutritional education programs can have an influence on children's knowledge, attitudes and behavior towards their eating habits ${ }^{(3)}$.

Momuna Tribe is a native tribe from the Dekai Subdistrict of Yahukimo District. The tribe Momuna community is divided into 12 villages in Dekai Subdistrict, four of which are the research sites, Kekey, Kiribun, Kokamu and Sokamu villages. Momuna's staple food is sago and cassava. In addition, the Momuna people also hunt for forest products such as wild boar, crocodiles, cassowaries, turtles, birds and fish. The way of processing these foods is still trasidional because of the lack of knowledge in managing food from sago and sweet potatoes to this day. Foods served for children should not be processed for food for toddlers. For example, sago, banana and sweet potatoes are only burned. Children consume what adults consume. So that many toddlers from the Momuna tribe experience malnutrition and this hinders their growth.

Based on the results of preliminary observations by researchers that tribes momuna do not have good knowledge in managing food for toddlers, especially women who have toddlers. The Momuna tribe community 
in these four villages is still slow to receive information because this community has adapted only a few years ago from the habit of living on trees.

\section{Purpose}

The purpose of this study was to determine the behavior of mothers in feeding the toddlers in the Momuna Tribe of Kekei, Koribun, Kokamu and Sokamu Village in Yahukimo district.

\section{METHODS}

The type of research in this study was observational with the cross sectional approach. The research was conducted April 2017 untill March 2018 in four villages namely Kekei, kiribun, kokamu and sokamu in Dekai Subdistrict, Yahukimo District. The Population in this study was toddlers aged 12-60 months as many as 228 toddlers. The sample in this study was toddlers aged 12-60 months as many as 112 toddlers. This study used sampling with multistage random sampling and secutive sampling, to obtain data from 112 mothers at the Posyandu. Inclusion criteria included mothers who had children aged 12 to 60 months, domiciled in the four villages. Exclusion criteria were mothers who have toddlers with chronic diseases that cause nutritional disorders, as well as toddlers with impaired growth and development. If the mother has more than one toddler, then the toddler was the smallest who was sampled. The data source used was primary data, namely questionnaire. Questions in the maternal knowledge questionnaire were assessed using the Guttman scale including 25 items. The total score was categorized to be less, if the correct answer was $<60 \%$, and good, if the answer was correct $>60 \%$. Questions in the mother's attitude and behavior questionnaire were assessed using a Likert scale with 15 items. The total score was then categorized by analogizing the standard assessment of knowledge variables. Data on toddlers was obtained from the $\mathrm{MCH}$ handbook, on the last visit. This research has gone through proper ethical and administrative processes. All respondents involved in this study have obtained informed consent.

\section{RESULTS}

\section{Characteristic of Respondents}

Table 1. Distribution of Mothers Characteristics in The Kekei, Kiribun, Sokamu and Kokamu Village of Dekai Subdistrict in Yahukimo District, 2018

\begin{tabular}{lcc}
\hline Variable & Frequency & Percentage \\
\hline Age of Mother (Years) & 0 & 0 \\
$\leq 20$ & 109 & 97 \\
$21-40$ & 3 & 3 \\
$41-65$ & & \\
& & \\
\hline Number of Children & 41 & 37 \\
1 & 47 & 42 \\
2 & 24 & 21 \\
$\geq 3$ & & 4 \\
\hline Education & 4 & 96 \\
Primary School & 108 & 100 \\
No School & & 0 \\
& & \\
\hline Occupation & 112 & \\
Working & 0 & \\
Not Working & &
\end{tabular}


Table 2. Distribution of Children Characteristics in The Kekei, Kiribun, Sokamu and Kokamu Village of Dekai Subdistrict in Yahukimo District, 2018

\begin{tabular}{lcc}
\hline Variable & Frequency & Percentage \\
\hline & & \\
Age of Children (Months) & & \\
$13-36$ & 72 & 64 \\
$37-59$ & 40 & 36 \\
\hline
\end{tabular}

Sex

Men $\quad 64 \quad 57$

Women $48 \quad 43$

Health Status

\begin{tabular}{lcc} 
Healthy & 35 & 31 \\
Ever/was sick & 77 & 69 \\
Cough & 24 & 21 \\
Heat & 21 & 19 \\
Diarrhea & 6 & 5 \\
Runny Nose & 24 & 21 \\
Others & 37 & 34 \\
\hline
\end{tabular}

Nutritional Status

\begin{tabular}{lcc} 
Very Thin & 99 & 88 \\
Thin & 13 & 12 \\
Normal & 0 & 0 \\
Fat & 0 & 0 \\
\hline
\end{tabular}

Based on Table 1 show the most mothers aged 21-40 years 97\%, more children as many as 1 child $37 \%$. Most mothers were not at least $96 \%$. All mothers work $100 \%$.

Based on Table 2 show the most of the age of toddlers aged 13-36 months 64\%, sex was more male, $57 \%$. Most of the toddlers had / were sick as much as $69 \%$. Most of the nutritional status of children under five was very thin at $88 \%$.

\section{Analysis of Behavior Mother}

Based on Table 3 show the most mothers have less knowledge of $92 \%$. Most mothers have less than $94 \%$ behavior. And fulfillment of nutrients as much as $87 \%$. 
Table 3. Distribution of Mother Behavior in The Kekei, Kiribun, Sokamu and Kokamu Village of Dekai Subdistrict in Yahukimo District, 2018

\begin{tabular}{ccc}
\hline \multicolumn{1}{c}{ Variable } & Frequency & Percentage \\
\hline Knowlegde & 103 & 92 \\
Less & 9 & 8 \\
Good & 112 & 100 \\
Total & & \\
\hline Behavior & 105 & 94 \\
Less & 7 & 6 \\
Good & 112 & 100 \\
Total & & \\
\hline Nutrition Fulfillment & 97 & 87 \\
Less & 15 & 13 \\
Good & 112 & 100 \\
Total & & \\
\hline
\end{tabular}

\section{DISCUSSION}

The majority of mothers are in the age range of 20-40 years or the early adult phase. In this phase, responsibility for parenting, including parenting in terms of nutrition is a natural life stage ${ }^{4}$. In addition, most mothers have two children. The results of this study are also relevant to the age of being in the productive range. The majority of respondents are uneducated. The results of this study are in line with research of Putri (2008) and demographic data of Yahukimo City in general ${ }^{(5)}$.

The data collection in this study was mostly carried out on weekdays starting at 08.00-12.00 at the Posyandu so that the data showed the majority of mothers were housewives. This also affects the knowledge and attitudes of mothers in the Momuna tribe. The majority of infants in this study were toddlers (13-36 months).

According to Erikson's psychosocial development, at this time children are in a period of autonomy versus hesitation/ shame. The age of 1-3 years, children receive food from what their mother provides. Therefore, toddlers are also called passive consumers. The results of the study also explain that the majority of toddlers are male. This result is also in accordance with the data of the Toddler weighing month (BPB) in 2012, where toddlers are male more than women ${ }^{(6)}$.

Health status of children in the past month is healthy. The results of this study are different from Hidayati (2011) research on family health tasks, family characteristics and children with nutritional status of children in the yahokimo region who say the majority of children experience illness ${ }^{(7)}$.

Based on the anthropometric index weight / height, it is known that the majority of children under five are malnourished. In addition, in this study also by Putri (2008) that found toddlers with very thin or thin nutritional status, found toddlers with poor nutritional status. The results of this study are lower when compared to research conducted.

The results showed that the majority of knowledgeable mothers were lacking in fulfilling toddler nutrition. This was different from the research conducted in Teluk Rumbia Village, Aceh, which found that the majority of knowledgeable mothers were lacking. The difference in the results of this study can be due to differences in categorization of knowledge variables ${ }^{(8)}$.

In the research of Ihsan et al. (2013) knowledge variables are distinguished to be good and not good, while in this study distinguished into good, sufficient, and less. In addition, differences in the characteristics of respondents or regions also influenced the results of the study. In this study, the majority of respondents did not attend school. Education is a factor that influences a person's nutritional knowledge. The higher the level of education of a person, the higher the ability of the person to capture information that can increase their knowledge $\mathrm{e}^{(9)}$. 
Based on the review of variables, it is known that respondents have less knowledge, the highest in subvariables choosing food, while having less knowledge, the highest in sub-variables is the problem of food and child nutrition. The researcher assumed that the knowledge of mothers who were lacking in choosing food was one of them because there was no sustainable counseling for mothers in this village. This makes it easier for mothers to get information about how to choose vegetables, fruits, meat, or fish that are good for children.

In the sub variables of child eating and nutrition problems, there are still many mothers who have less knowledge due to the limited knowledge of mothers about the term nutrition problems in children, for example, such as the term KEP (lack of energy protein). Based on the results of the analysis, it can be seen that respondents with good knowledge, their nutritional status are lacking. Mothers who had good knowledge, had children with good nutritional status. The results of the study on the attitudes of mothers in fulfilling toddler nutrition found data that the majority of mothers have less attitudes ${ }^{(10)}$. In addition, The majority of mothers have a good attitude in fulfilling child nutrition ${ }^{(11)}$.

The difference in the results of this study with the research of Vereecken, et.al (2010) can be influenced. by the characteristics of the research respondents. In the Veerecken and Maes study, the majority of mothers had higher education levels, while in this study the majority of mothers had low levels of education. One component of forming attitudes is the cognitive or knowledge component, where the component is influenced by one's level of education. Several factors that can influence a person's attitude can include individual experience, the influence of people who are considered important, and culture. Based on the subvariable review, it was found that the respondents had less attitudes, most of them were sub-variables of child eating and nutrition problems. Meanwhile, the respondents had less attitudes, most in the subvariable choosing food. When associated with the discussion of subvariables of knowledge, this is certainly different from previous studies which state that one's knowledge influences his attitude ${ }^{(12)}$.

Then, subvariable eating and nutritional problems of children. Researchers assume that even though mothers have limited knowledge in knowing the term feeding problems and child nutrition, mothers have the willingness and desire to prevent nutritional problems in children, so that their attitude is good. This is evidenced by the results of the analysis stating that all mothers will continue to provide balanced food to children even though their children have difficulty eating. The results of the analysis in this study indicate that good nutritional status of children is motivated by maternal attitudes in fulfilling child nutrition. This is supported by Pratama's research (2012) which states that there is a significant influence between attitudes of mothers and nutritional status of children. toddlers with less nutritional status than mothers who have a good attitude $^{(13)}$.

In this study it is known that the majority of mothers have good behavior in fulfilling toddler nutrition. The results of this study are in line with research conducted by Huriah (2006) which suggest that the majority of mothers have good behavior in fulfilling gizianak ${ }^{(14)}$. According to Precede's theory, The factors that shape a person's behavior include predisposing factors, enabling factors, and reinforcing factors ${ }^{(15)}$. The results of this study are in line with Azwar (2007) that Predisposing factors that influence good maternal behavior in this study are knowledge and attitudes. Toddler nutrition is the basis for the formation of attitudes and ultimately can form good behavior. ${ }^{(12)}$

When viewed by variables, respondents have less behavior, the highest in terms of processing food, while having the lowest behavior in choosing food. According to the theory, one of the things that influences a person's behavior is the person's attitude ${ }^{(16)}$. In terms of choosing food, this poor mother's behavior is based on her attitude that is also not good. Then, researchers assume that a good mother's attitude about eating and nutrition problems also contributes to good behavior in terms of processing food. This is because one strategy to overcome the problem of eating in children is to create food processing methods. In this study there is a tendency that the better the behavior of mothers in fulfilling children's nutrition, the better the nutritional status of children. Mothers who have good behavior in fulfilling nutrition have children with good nutritional status ${ }^{(17)}$.

\section{CONCLUSION}

The majority of respondents have a level of lack of knowledge, lack of attitudes, and behaviors that are lacking in the fulfillment of toddlers' nutrition. The results of this study can help nurses in developing strategies needed to improve maternal knowledge, attitudes, and behavior related to child nutrition to a better level. Subsequent research needs to be done using different sampling techniques, involving mothers who have infants aged 6-59 months, and can use observation methods to measure the variable behavior of mothers.. 


\section{REFERENCES}

1. Kemenkes RI. Basic Health Research 2010 (Riset Kesehatan Dasar / Riskesdas 2010) [Internet]. Badan Penelitian dan Pengembangan Kesehatan Kementerian Kesehatan Republik Indonesia. 2010 [cited 2018 Apr 16]. Available from: http://www.riskesdas.litbang.depkes.go.id/download/TabelRiskesdas2010.pdf

2. Budiyanto MAK. Basics of Nutrition (Dasar-dasar Ilmu Gizi). Malang: UMM Press; 2002. p. 149.

3. Soekiman. Nutrition Science and Its Application for Family and Society (Ilmu Gizi dan Aplikasinya Untuk Keluarga dan Masyarakat). Jakarta: Departemen Pendidikan Nasional Republik Indonesia; 2000.

4. Potter, Perry. Textbook on Fundamental Nursing Concepts, Processes, and Practices (Buku Ajar Fundamental Keperawatan Konsep, Proses, dan Praktik). Ed. 4 Vol.1. EGC. Jakarta; 2005.

5. Putri RNA. Factors Related to Nutritional Status of Children based on Body Mass Index According to Age in The Work Area of Pancoran Mas Depok Health Center in 2008 (Secondary Data Analysis) (Faktor-Faktor Yang Berhubungan Dengan Status Gizi Baduta Berdasarkan IMT Menurut Umur di Wilayah Kerja Puskesmas Pancoran Mas Depok Tahun 2008 (Analisis Data Sekunder). Undergraduate Thesis. Depok: Faculty of Public Health, Universitas Indonesia; 2008.

6. Uripi V. Healthy Menu for Toddlers (Menu Sehat Untuk Balita). Jakarta: Puspa Swara Publisher; 2004.

7. Hidayati RN. Relationship Between Family Health Duties, Family Characteristics and Children with Nutritional Status of Children In The Pancoran Mas Community Health Center, Depok City (Hubungan Tugas Kesehatan Keluarga, Karakteristik Keluarga dan Anak Dengan Status Gizi Balita di Wilayah Puskesmas Pancoran Mas Kota Depok). Postgraduate Thesis. Depok: Faculty of Nursing; Universitas Indonesia; 2011.

8. Ihsan M, Hiswani, Jemadi. Factors Related to Nutritional Status of Children Under Five in The Bay Village of Rumbia, Singkil District, Aceh District in 2012 (Faktor-Faktor yang Berhubungan Dengan Status Gizi Anak Balita di Desa Teluk Rumbia Kecamatan Singkil Kabupaten Aceh Singkil Tahun 2012). Jurnal Gizi, Kesehatan Reproduksi dan Epidemiologi. 2013;2(1):1-10.

9. Khomsan A. Techniques for Measuring Nutrition Knowledge (Teknik Pengukuran Pengetahuan Gizi). Bogor: Institut Pertanian Bogor; 2000.

10. Khotimah NS, Siregar R, Mardiana. Relationship Between Knowledge of Maternal Nutrition and Diet for Toddlers with Nutritional Status of Children (12-59 Months) in The Working Area of The Gandus Public Health Center in Gandus-Palembang District in 2010 (Hubungan Pengetahuan Gizi Ibu dan Pola Makan Balita Dengan Status Gizi Balita (12-59 bulan) di Wilayah Kerja Puskesmas Gandus Kecamatan Gandus-Palembang Tahun 2010). Jurnal Pembangunan Manusia; 2012;6(2).

11. Vereecken C, Maes L. Young Children's Dietary Habits And Associations with The Mothers Nutritional Knowledge And Attitudes. Appetite. 2010; (54)44-51.

12. Azwar S. Human Attitude: The Theory And Measurement (Sikap Manusia: Teori dan Pengukurannya) Yogyakarta: Pustaka Pelajar; 2007.

13. Pratama. Effect of Education Level, Income Level, Mother's Knowledge, Mother's Attitude, and Mother's Behavior on Nutritional Status of Children In Kecamben Sub-District, Jombang Regency (Pengaruh Tingkat Pendidikan, Tingkat Pendapatan, Pengetahuan Ibu, Sikap Ibu, Dan Perilaku Ibu Terhadap Status Gizi Balita di Kecamatan Kesamben Kabupaten Jombang). Undegraduate Thesis. Surabaya: Universitas Negeri Surabaya; 2012.

14. Huriah T. Relationship between Maternal Behavior in Meeting Nutritional Needs with Toddlers' Nutritional Status in Beji Subdistrict, Depok City (Hubungan Perilaku Ibu dalam Memenuhi Kebutuhan Gizi dengan Status Gizi Batita di Kecamatan Beji Kota Depok). Thesis. Depok: Faculty of Nursing; Universitas Indonesia; 2006.

15. Binkley CJ, Johnson KW. Application of The PRECEDE-PROCEED Planning Model In Designing An Oral Health. 2013

16. Notoatmodjo S. Health Promotion and Behavioral Sciences (Promosi Kesehatan dan Ilmu Perilaku). Jakarta: Rineka Cipta; 2007.

17. Jelantik. Differences in Feeding Behavior By Mothers Who Have Children Under Five With Poor Nutrition With Nutrition Both in The Working Area of The Pringgasela Health Center in East Lombok District in 2012 (Perbedaan Perilaku Pemberian Makanan oleh Ibu yang Memiliki Anak 
Balita Gizi Buruk Dengan Gizi Baik di Wilayah Kerja Puskesmas Pringgasela Kabupaten Lombok Timur tahun 2012). Media Bina Ilmiah. 2012;6(4);48-52. 